\title{
FOGSI Presidential Inaugural Address
}

\section{Balsarkar G.}

Published online: 26 April 2013

(C) Federation of Obstetric \& Gynecological Societies of India 2013

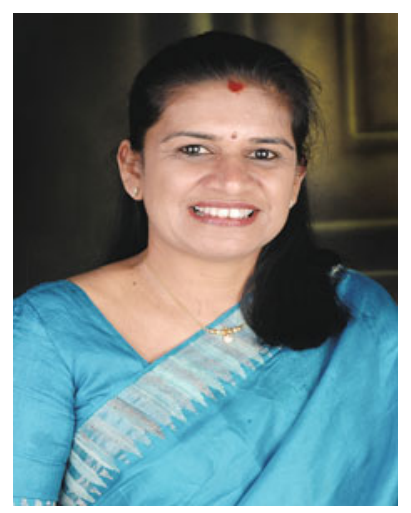

\section{Dr. HEMA DIVAKAR SPEAKS......}

My dear fellow FOGSI'ans,

Namaskar!

I wish to thank one and all for electing me as President for the year 2013. With the support of all the FOGSI'ans, I feel confident, optimistic, excited, and enthusiastic to begin my responsibility of carrying forward the work of this prestigious organization.

This organization has offered great opportunities and led me to embrace several challenges - the most recent one is

Balsarkar G. $(\square)$

FOGSI, Mumbai, India

e-mail: jlnobgynspinger@gmail.com that of the position of PRESIDENT FOGSI 2013, and I thank you for your trust. I am aware of the responsibilities of leading this mammoth organization. I truly believe that leadership is not about position, it is about ACTION.... "Be realistic_plan for a miracle." That's been my mantra. I had thought to myself that if I ever become the president of FOGSI, I should be installed in MUMBAI... the place where I studied and grew up and I should have the presence and blessings of my very beloved teacher, Dr. S.N.Daftary, who saw a great potential in me, years ago ! This has become a reality this evening.

I recognize that my family, and team Bengaluru, and team south India, have waited so long this evening to witness this installation ceremony, and we will all soon see the year go by swiftly with many dreams being turned into action-and I do hope to witness many more miracles to change the face of women's healthcare in India.

Everyone in the world today recognizes that India's progress over the last 20 years has been quite phenomenal. The country has witnessed advancements in all fields but India remains "The Perpetual Paradox." Bias against a girl child is still prevailing in the country. She faces vulnerability to violence at every stage of her life-cycle. We, at FOGSI, now recognize our responsibilities beyond healthcare-encompassing not only medical, but also the social, legal, and economic ramifications. Sex-selective abortion still prevails and the "save the Girl child" initiatives work toward ensuring that "SHE is born." But, that's just the beginning..... We have to educate her, ensure safe delivery, and empower her to age gracefully. 
Honorable Union Health Minister Ghulam Nabi Azadji, who is the invited guest today, admitting that a huge population is a huge challenge, especially those in rural India, said that Public-Private Partnership Model (PPP) needs to be explored in a big way and stressed the need for creating facilities that are affordable to all. Honorable Chief Minister of Maharashtra, Shri Prithviraj Chavanji has said he will be requesting the Bombay High Court to allocate 25 fast track courts exclusively to bring fast results in cases of crime against women. The government initiatives through Gender Responsive Budgeting, GOI campaign on "Happy girl is the future of our country," National policy for women empowerment, JSY/108 and other incentives for institutional deliveries, and the FOGSI partnership with EmOC/PCPNDT/ANTI VIOLENCE CELL/DOSST cells are examples of the several efforts toward offering equal opportunities and ensuring safety for girls and women.

What has been achieved is indeed commendable, but considering the sheer size of our country, what still needs to be done presents a huge challenge. It is true that you can spend a lifetime in India and be none the wiser in trying to understand India's vast complexities. We need to Learn to turn Challenges into Opportunities and Problems into Solutions. We need to figure out what works for us:

The challenge is-india is home for 1.2 billion

The opportunity is-Harness the Human Resource

The challenge is-India is a land of widely varying religions, cultures, and levels of wealth

The opportunity is-Build public-private partnerships.

We know it is not going to be easy, but most things are difficult before they are easy... Bill Gates has remarked: "A lot of progress has come from the nation's culture of innovation, which has produced some really original and creative solutions....." We have plenty of ideas and the time has now come for effective implementation of innovative methods suited for our country's needs. Hence the FOGSI 2013 theme is aptly coined as "Innovation to Implementation" The theme for FOGSI 2013 is

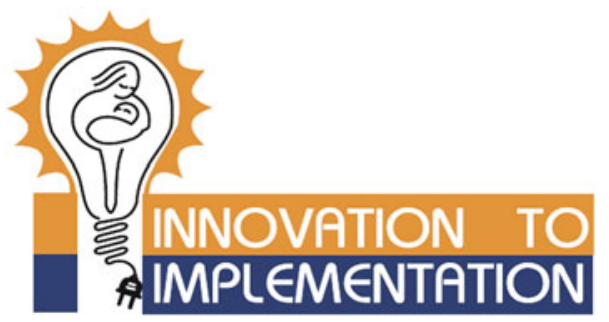

We are proud to have many THOUGHT LEADERS for INNOVATIVE IDEAS , and we need the energy, enthusiasm, and commitment of YOUTH LEADERS for IMPLEMENTATION.
To address the issues of PAST, PRESENT, and FUTURE in the sphere of women's health care, we work on the following concepts:

[1] Consider the Past: Help Mothers Survive [HMS]

[2] Evaluate the Present: Keep Educating Yourself [KEY]

[3] Create the Future: Yuva Toward Tomorrow [YTT]

These are the three main stream opportunities laid out for the members for participation and action in the year 2013

\section{Consider the Past: Help Mothers Survive [HMS]}

The most pressing need of the hour is to save the mothers. Every $90 \mathrm{~s}$, around the world, a woman dies from complications of pregnancy or childbirth, yet the vast majority of maternal deaths globally are preventable. According to the United Nations, "Maternal mortality is not just a personal tragedy. It is not just a development, humanitarian and health issue. Maternal mortality is a human rights issue." An emphasis on making emergency obstetric care available to all women who develop complications is central to reducing maternal mortality. According to Mahmoud Fathalla, past president of the International Federation of Obstetricians and Gynaecologists, "there is an unfortunate saying in many developing countries." Any fool can catch a baby. "In the 21 st century world, there are still millions of women who have access only to fools to catch their babies."

Post-partum hemorrhage (PPH) and pre-eclampsia/ eclampsia (PE/E) continue to remain the two major causes of maternal mortality.

We launch FOGSI Jhpiego Emcure fast track initiative to Help Mothers Survive.

The program is a low dose high intensity Focused training and capacity building of Frontline Health care Providers to handle PPH and PE/E.

The mission is to train all the Frontline Healthcare Providers to prevent, recognize and treat Postpartum Haemorrhage and Pre-eclampsia/Eclampsia...

The HMS fast track initiative will use the Innovative module of Mammanataalle for the training programs. The FOGSI fast track teams (led by Vice-presidents Dr. Alpesh and Dr. Jayanth) will lead the project through master trainers who have received the technical training by Jhpiego. This will be run with the teams in 100 medical colleges pan India and also in all the Ob Gyn Societies. Every post graduate will be sensitized to protocol-based practices for AMSTL, PPH, and PE/E.

This is especially important in the backdrop of the fact that Path Study has revealed $0 \%$ adherence to AMSTL and Dr. Gupte's study has brought to light that fewer than half 
the number of cases of eclampsia have received Mag sulf injection.

We need your active involvement for this initiative translating into preventing needless deaths--Everyone can be a champion to Help Mothers Survive.

This will make an impact on reducing MMR.

"We can't help everyone-but everyone can help someone" Ronald Regan.

I am thankful to Dr. Harshad Sanghvi, the Vice president and Medical Director of Jhpiego, for giving me insights into public health programs and constantly supporting, motivating, and inspiring me to do more.

\section{Evaluate the Present: Keep Educating Yourself [KEY]}

Pan India CME Programs

The fields of medicine and science never stop moving forward—and neither should physicians. Medicine changes rapidly with new scientific information and technology. To keep up-to-date with these changes, doctors learn all through their professional lives. We need to study the ground realities in the Indian context-social, cultural, and economic inequalities which present several constraints in offering the best practices.

"Don't let the Best come in the way of Good" Operational research and many programmatic successes have shown the way for innovative, low-cost, and feasible practices for India. Dr. Isaac Manyonda (UK) has been largely instrumental in driving the research initiatives and publications on IV IRON SUCROSE/SINGLE STEP TEST FOR GDM/PPIUCD/KAP on HPV Vaccines.

There is an opportunity in the KEY-CME programs in every Ob Gyn Society of India to share the evidence in the Indian context and see what works for us. We hope that you will actively participate in the deliberations, and share your experiences in problem solving with the spirit of "each one teach one."

The KEY programs will share

- KEY facts

- KEY messages

- KEY findings from Indian studies

- KEY recommendations

The Vision 2022 for women's health in India on the basis of ABCDE projects is to decrease the burden of Anemia, Population explosion, Cancer cervix, and Diabetes and evolve innovative low-cost but quality care for women, packaged with compassion and respect for women.
Impact will be uniform standards for the practices in India, development of Indian Guidelines, and translating them into policies for practice in INDIA.

KEY-Keep Educating Yourself: Each one teach one (CMEs in every society)

FOGSI MSD KEY PROGRAM-Cancer cervix-Kill it before it kills you

FOGSI MSD KEY PROGRAM-Building contraceptive choices

FOGSI HLL KEY PROGRAM-Building contraceptive choices

FOGSI CIPLA KEY PROGRAM-Building contraceptive choices

FOGSI BAYERS KEY PROGRAM-Building contraceptive choices

FOGSI EMCURE KEY PROGRAM-Save the Mothers FOGSI Uth Health KEY PROGRAM-Single Step to stop Diabetes

FOGSI TORRENT KEY PROGRAM-Save the Uterus FOGSI WELLESIA KEY PROGRAM-PCOS UPDATE

FOGSI ACKUMENTIS KEY PROGRAM-PROGESTERONE UPDATE

FOGSI GSK KEY PROGRAM-ADOLESCENCEACT NOW!

FOGSI WANBERY KEY PROGRAM-9 months 9 challenges!

Initiatives with Networking Partners

We are proud to announce the collaboration with Public Health Foundation of INDIA (FOGSI PHFI) and that we will be launching courses on "Contraception" and "GDM" at 50 centers pan India.

"Investment in Knowledge pays the best interest" Benjamin Franklin.

With Emcure pharma as our leading educational partners, we will host several regional and national and international Congresses, inclusive of YOUTH LEADERS SUMMIT in Bengaluru.

\section{Create the Future: Yuva Toward Tomorrow [YTT]}

Albert Einstein said "Learn from yesterday, live for today and hope for tomorrow." The YTT series of programs will enhance technical skill development and prepare the young doctors for future challenges. Young people need models, not critics. I urge the senior members to contribute to the learning process of the youth leaders of tomorrow. 
I believe that we have all at sometime eaten the fruits from the trees that we did not plant. In the fullness of time, when it is our turn to give, we have to plant gardens which will largely benefit the generations to come. The postgraduate programs called the FORCE and the workshops in Endoscopy, Colposcopy, Ultrasonology, Infertility, Skill drills, and Communications for the YUVA are fueled by enthusiasm of joint secretary Dr. Vidya Bhat and team Bengaluru. We hope this will help the YUVA work with alacrity and confidence and strive to make India the world class destination of women's healthcare.

The impact will be the creation of many YOUTH LEADERS.

\section{YUVA Congress and Other Events}

APRIL 5, 6, 7-EAST ZONE YUVA FOGSI, GAUHATI THEME: "DON'T LET MOTHERS DIE"

JUNE 7, 8-YOUTH LEADERS SUMMIT Bengaluru Theme: ACT \& IMPACT 2013

JULY 13, 14-CRITICAL CARE CONGRESS, PUNE AUGUST16,17,18-SOUTH ZONE YUVA FOGSI TRICHY THEME: "HIGH RISK PREGNANCY" SEPTEMBER 6,7,8-WESTZONE YUVA FOGSI BHOPAL THEME: "CATCH 22-The Adolescent" Septemberi 2 i 14,15-INTERNATIONAL CONGRESS, HYDERABAD

NOVEMBER 15,16,17-NORTH ZONE YUVA FOGSI, AMRITSAR THEME: "MID LIFE-THE NEW BEGINNINGS"

DECEMBER 1-CHENNAI DIP-DIABETES IN PREGNANCY SUMMIT

In the ultimate analysis, we are all merely the temporary custodians of financial, intellectual, and emotional wealth, which we have generated through FOGSI. We start by doing what is necessary, then what is possible, and suddenly we are doing the impossible!

The supports from the networking agencies, NGOs, and Government of India; the commitment from the past Presidents-Drs. CN Purandare, Sanjay Gupte, PC Mahapatra, and PK Shah, and the senior advisors; the balanced inputs from Dr. NozerSheriar, SuchitraPandit, HrishekeshPai, and the rest of the office bearers, the dynamic chairpersons, and FOGSI office staff-and the willingness of every FOGSI member-good wishes from all sectors will collectively help team FOGSI 2013 to ACT \& IMPACT.

Team FOGSI 2013; my Vice-presidents Drs. Alpesh Gandhi, Ashwini Bhalerao, Shantakumari, Jayanth rath, and Maninder Ahuja; Joint Secretary Dr. Vidya Bhat; the FOGSI office bearers; and the staff believe that "As is our confidence, is our capacity."

We have recognized the magnitude of the problem, formulated what should be done, and now we need to act so as to impact the change.

You are our strength and will be the catalyst for the change we want to see in Women's Health Care in India.

In addition to these three main stream programs, a lot more will happen as the year rolls out. I invite all of you to be a part of Team FOGSI 2013 and together we will work toward a common goal of improving women's health. We will immensely value your support and participation in FOGSI activities, and we look forward to a fruitful year ahead.

Focus on the results and there will be less time for dispute.

Leave the arguments to your rivals.

Invest your time in creating excellence.

-Mahatma Gandhi

Join us in the journey in 2013.

\section{"INNOVATION 2 IMPLEMENTATION"}

I remain in the attitude of gratitude to my parents, teachers, family, friends, and of course, to fellow FOGSI' ans.

I am honoured and humbled by the trust reposed in me. I thank each one of you once again,

warm regards

Dr. Hema Divakar President FOGSI 2013 